\title{
Effects of $\mathrm{C}$ and $\mathrm{N}$ additions on primary MAX phase particles in intermetallic Ti-Al-Nb-Mo matrix in-situ composites prepared by vacuum induction melting
}

\author{
A. Klimová*, J. Lapin \\ Institute of Materials and Machine Mechanics, Slovak Academy of Sciences, \\ Dúbravská cesta 9, 84513 Bratislava 3, Slovak Republic
}

Received 19 February 2019, received in revised form 15 March 2019, accepted 18 March 2019

\begin{abstract}
The effects of $\mathrm{C}$ and $\mathrm{N}$ additions on primary MAX phase particles were studied in in-situ intermetallic matrix composites with nominal composition Ti-37Al-3.8Nb-1Mo-0.1B- $x$ C- $y \mathrm{~N}$ (at.\%), where $x+y=5$ at.\%. The in-situ composites were prepared by vacuum induction melting and solidification in graphite crucibles. The increasing content of $\mathrm{N}$ in the studied in-situ composites decreases the solubility of $\mathrm{Nb}$ in the primary $(\mathrm{Ti}, \mathrm{Nb})_{2} \mathrm{Al}(\mathrm{C}, \mathrm{N}) \mathrm{MAX}$ phase particles and leads to a partial substitution of $\mathrm{C}$ by $\mathrm{N}$ in them at the expense of increasing content of $\mathrm{N}$ in lamellar $\alpha_{2}\left(\mathrm{Ti}_{3} \mathrm{Al}\right)+\gamma(\mathrm{TiAl})$ matrix. The shape factor increases and volume fraction and size of the MAX phase particles decrease with increasing content of $\mathrm{N}$. The increasing content of $\mathrm{N}$ in the composites has no significant effect on nanohardness of the primary particles but increases their elastic modulus.
\end{abstract}

K e y w ords: intermetallics, composites, MAX phases, microstructure, hardness

\section{Introduction}

Carbon and nitrogen as interstitial elements exhibit different solubility limit in $\alpha(\mathrm{Ti})-, \alpha_{2}\left(\mathrm{Ti}_{3} \mathrm{Al}\right)-$, $\gamma(\mathrm{TiAl})-, \beta(\mathrm{Ti})-$, and $\beta / \mathrm{B} 2$-phases which are formed in TiAl-based alloys during solidification and heat treatments. Moreover, their solubility in these phases is affected by the presence of other additional alloying elements such as $\mathrm{Nb}, \mathrm{Mo}$ and $\mathrm{Cr}$ [1-6]. Due to a smaller atomic radius of nitrogen than that of carbon, the average solubility limit of $\mathrm{N}$ is assumed to be higher than the solubility limit of $\mathrm{C}[7,8]$. After exceeding the solubility limit, two types of particles are formed in the $\mathrm{C}$ and $\mathrm{N}$ doped TiAl-based alloys of engineering interest: (i) $\mathrm{Ti}_{3} \mathrm{AlC}$ or $\mathrm{Ti}_{3} \mathrm{AlN}$ with perovskite $c P 5$ crystal structure and (ii) MAX phases of $\mathrm{Ti}_{2} \mathrm{AlC}$ or $\mathrm{Ti}_{2} \mathrm{AlN}$ type with hexagonal $h P 8$ crystal structure $[4,9]$. The MAX phases ( $\mathrm{M}$ is a transition metal, $\mathrm{A}$ is an A-group element, and $\mathrm{X}$ is nitrogen or carbon) display a unique combination of metallic and ceramic properties [10]. Coarse primary $\mathrm{Ti}_{2} \mathrm{AlC}$ and $\mathrm{Ti}_{2} \mathrm{AlN}$ particles have shown a significant role in toughening and reinforcing of in-situ TiAl-based matrix composites prepared by melting and casting techniques $[4,9,11-16]$. The $\mathrm{Ti}_{2} \mathrm{AlC}$ particles increase compressive strength, impact energy, fracture toughness, and improve high temperature creep resistance of TiAl-based matrix composites [14, 17-20]. Carbon and nitrogen can substitute each other in the MAX phase forming $\mathrm{Ti}_{2} \mathrm{Al}\left(\mathrm{C}_{n}, \mathrm{~N}_{(1-n)}\right)$ carbonitride. The lattice parameters of the carbonitride $a$ and $c$ depend on the content of $\mathrm{C}$ and $\mathrm{N}$; the smallest are in the pure nitride and the largest in the pure carbide $[10,21]$. The partial substitution of $\mathrm{C}$ by $\mathrm{N}$ in bulk $\mathrm{Ti}_{2} \mathrm{AlC}$ increases its strength and elastic modulus [10, 22]. Similar changes of the lattice parameters are caused by the substitution of $\mathrm{Nb}$ for $\mathrm{Ti}$ in $\left(\mathrm{Ti}_{n}, \mathrm{Nb}_{(1-n)}\right)_{2} \mathrm{AlC}$ with the highest unit cell volume for $\mathrm{Nb}_{2} \mathrm{AlC}[23,24]$. The substitution of $\mathrm{C} / \mathrm{N}$ and $\mathrm{Ti} / \mathrm{Nb}$ in bulk MAX $\mathrm{Ti}_{2} \mathrm{Al}\left(\mathrm{C}_{n}, \mathrm{~N}_{(1-n)}\right)$ and $\left(\mathrm{Ti}_{n}, \mathrm{Nb}_{(1-n)}\right){ }_{2} \mathrm{AlC}$ phases has been studied by several authors [21, 23, 24]. However, information about the mutual influence of $\mathrm{C}$ and $\mathrm{N}$ additions on the formation, chemical composition, size, morphology and properties of primary MAX

*Corresponding author: tel.: +421 23240 1055; e-mail address: alena.klimova@savba.sk 
Table 1. Chemical composition of the composites (at.\%)

\begin{tabular}{lcccccc}
\hline \multirow{2}{*}{ Composite } & \multicolumn{5}{c}{ Element } \\
\cline { 2 - 7 } & $\mathrm{Al}$ & $\mathrm{Ti}$ & $\mathrm{Nb}$ & $\mathrm{Mo}$ & $\mathrm{N}$ & $\mathrm{C}$ \\
\hline $\mathrm{C} 5.0$ & $37.9 \pm 0.3$ & $52.1 \pm 0.3$ & $3.9 \pm 0.1$ & $1.0 \pm 0.1$ & $0.1 \pm 0.1$ & $5.0 \pm 0.1$ \\
C2.5N2.5 & $36.9 \pm 0.3$ & $53.4 \pm 0.2$ & $3.9 \pm 0.1$ & $1.0 \pm 0.1$ & $2.3 \pm 0.1$ & $2.5 \pm 0.1$ \\
N5.0 & $37.0 \pm 0.3$ & $53.1 \pm 0.2$ & $3.7 \pm 0.1$ & $1.0 \pm 0.1$ & $4.7 \pm 0.1$ & $0.1 \pm 0.1$ \\
\hline
\end{tabular}

phase particles in cast intermetallic TiAl-based matrix composites [25] are very limited, particularly in the systems alloyed at the same time with $\mathrm{Nb}$ and Mo. Therefore, it is of large interest to investigate the mutual effects of these alloying elements on the formation and properties of primary MAX phase particles in in-situ TiAl-based matrix composites prepared by cost-effective melting and casting technologies.

This paper aims to study the effect of $\mathrm{C}$ and $\mathrm{N}$ additions on primary MAX phase particles in intermetallic Ti-Al-Nb-Mo matrix in-situ composites prepared by vacuum induction melting and solidification in graphite crucibles.

\section{Experimental procedure}

The samples of intermetallic matrix composites with a diameter of $42 \mathrm{~mm}$, length of $15 \mathrm{~mm}$ and nominal compositions Ti-37Al-3.8Nb-1Mo-0.1B- $x$ C$-y \mathrm{~N}$ (at.\%), where $x+y=5$ at. $\%$, were prepared by vacuum induction melting of the master alloy with addition of $\mathrm{TiC} / \mathrm{TiN}$ powders in graphite crucibles. The vacuum chamber of the induction melting furnace was evacuated before melting to a vacuum pressure of $8 \mathrm{~Pa}$ and flushed with argon (purity 99.9995\%) three times. The charge was induction heated to a melt temperature of $1690^{\circ} \mathrm{C}$ and held at this temperature for $120 \mathrm{~s}$ under an argon pressure of $2 \mathrm{kPa}$. The temperature of the melt was measured by a pyrometer. The solidification of the melt was carried out in the graphite crucibles by switching off the induction heating of the furnace. Microstructure investigations were performed by scanning electron microscopy with the detection of the backscattered electrons (BSEM) and X-ray diffraction analysis (XRD) using diffractometer Bruker D8 and the database PDF-2 2004. The chemical composition of the alloys was analysed by energy-dispersive spectroscopy (EDS) and wavelength-dispersive spectroscopy (WDS) using JSM-6610 and JEOL 7600F scanning electron microscopes equipped with EDS and WDS detectors. The EDS and WDS systems applied for the measurements of the chemical composition of MAX phases and matrices were calibrated using standards. BSEM, XRD, EDS and WDS samples were prepared using standard grinding, polishing and etching metallographic techniques. Average oxygen and ni- trogen contents were measured by elemental LECO ONH836 and carbon content by LECO CS844 elemental analysers based on combustion method. Size, morphology and volume fraction of the coexisting phases were determined from the digitalized micrographs using computer image analyzer. Indentation nanohardness and elastic modulus measurements were carried out using ASMEC-Zwick/Roell nanoindenter with Berkovich tip of the indenter at an applied load of $0.01 \mathrm{~N}$ with the application of fast hardness and modulus measurement method.

\section{Results and discussion}

\subsection{The chemical composition of the in-situ composites}

The average chemical composition of the as-solidified in-situ composites designated as C5.0, C2.5N2.5 and N5.0 is shown in Table 1. The sample C5.0 contains 5 at.\% of carbon and just a small amount of nitrogen. The sample N5.0 contains 4.8 at. $\%$ of nitrogen and a small amount of carbon. The content of $\mathrm{C}$ and $\mathrm{N}$ in the sample $\mathrm{C} 2.5 \mathrm{~N} 2.5$ is measured to be 2.5 and 2.3 at.\%, respectively. The average amount of $\mathrm{Nb}$ in the studied samples is (3.8 \pm 0.1$)$ at. $\%$, and the content of Mo is 1 at. $\%$. It should be noted that the content of oxygen does not exceed 900 wt.ppm in the studied in-situ composites.

\subsection{Microstructure and phase composition}

Figure 1 shows the typical microstructures of the in-situ composites C5.0, C2.5N2.5 and N5.0. The shape of the primary particles changes from plate-like in the C5.0 to nearly regular or irregular clustered one in the N5.0, as seen in Figs. 1a,c,e. Assuming a relationship for circularity in the form $F=\left(4 \pi A / P^{2}\right)$, where $A$ is the area and $P$ is the perimeter, the shape factor $F$ of the particles increases from 0.42 to 0.61 with increasing content of $\mathrm{N}$. The primary particles (1 and 2) are distributed in the matrix composed of lamellar (3) and single phase (4) regions, as shown in Figs. 1b,d,e,f.

The XRD patterns in Fig. 2 indicate that the matrices of the studied in-situ composites consist 

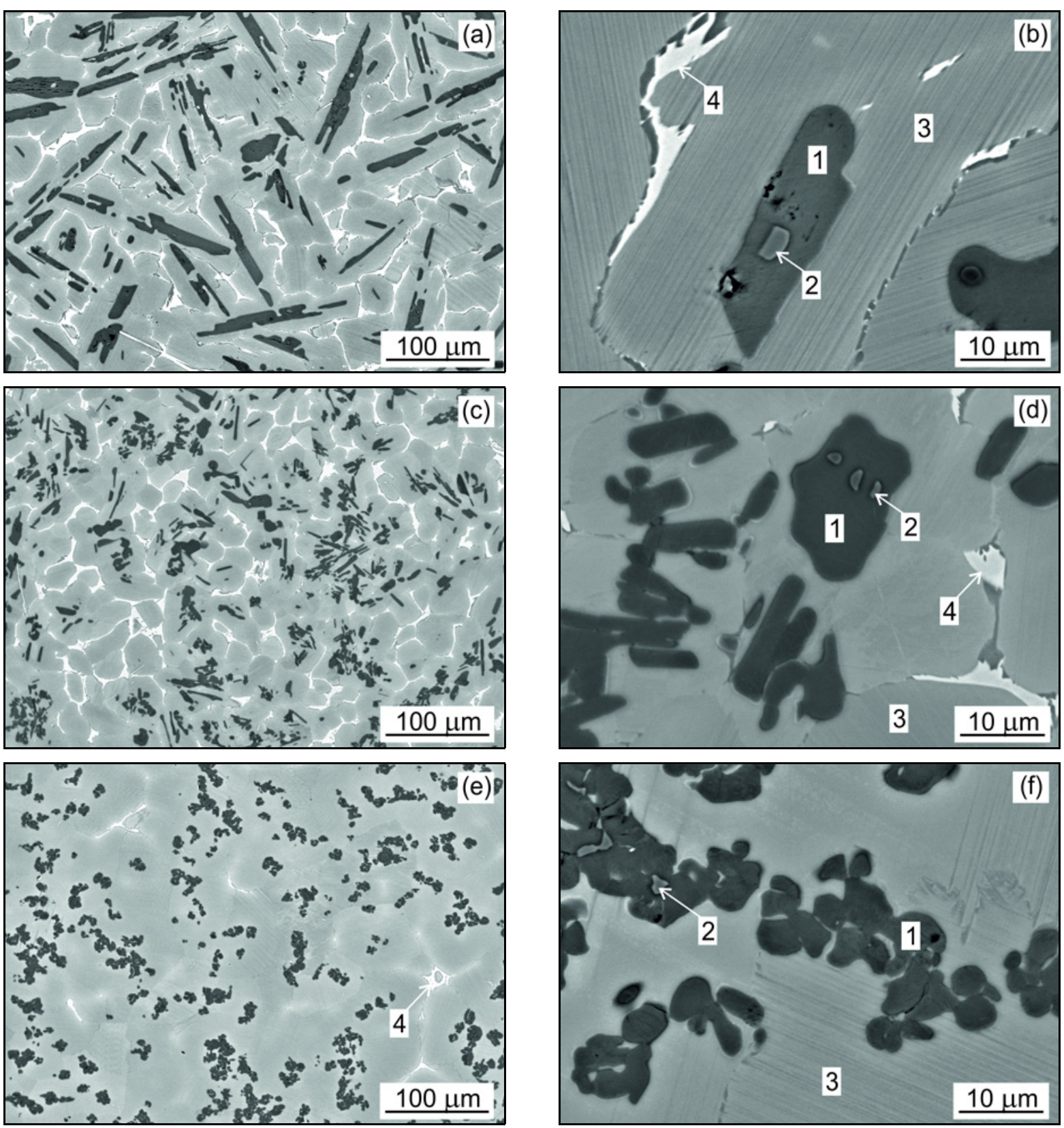

Fig. 1. BSEM micrographs showing the typical microstructure of the in-situ composites: (a), (b) C5.0; (c), (d) C2.5N2.5; (e), (f) N5.0.

of three phases: $\alpha_{2}\left(\mathrm{Ti}_{3} \mathrm{Al}\right), \gamma(\mathrm{TiAl})$ and $\beta / \mathrm{B} 2$ (disordered/ordered cubic phase). The crystal structure of the primary particles belongs to hexagonal $(h P 8) \mathrm{Ti}_{2} \operatorname{Al}\left(\mathrm{C}_{n}, \mathrm{~N}_{(1-n)}\right)$ and fcc $(c F 8) \operatorname{Ti}\left(\mathrm{C}_{n}, \mathrm{~N}_{(1-n)}\right)$ phases. A decrease of the lattice parameters in the MAX phase particles with the increasing amount of nitrogen at the expense of carbon $[10,21]$ is visible in the XRD patterns, where the peaks of $\mathrm{Ti}_{2} \mathrm{Al}(\mathrm{C}, \mathrm{N})$ in the composite $\mathrm{C} 2.5 \mathrm{~N} 2.5$ are shifted to the higher $2 \Theta$ angles compared to the peaks of $\mathrm{Ti}_{2} \mathrm{AlC}$ phase in the C5.0.

The EDS maps (Fig. 3) and point analyses (Table 2) indicate that $\mathrm{Nb}$ is present in the carbide parti- cles, so the particles formed in the C5.0, C2.5N2.5 and $\mathrm{N} 5.0$ in-situ composites belong to the $(\mathrm{Ti}, \mathrm{Nb})_{2} \mathrm{AlC}$, $(\mathrm{Ti}, \mathrm{Nb})_{2} \mathrm{Al}(\mathrm{C}, \mathrm{N})$ and $(\mathrm{Ti}, \mathrm{Nb})_{2} \mathrm{AlN}$ phases, respectively. A small amount $(0.6$ vol.\%) of $(\mathrm{Ti}, \mathrm{Nb}) \mathrm{C}$, $(\mathrm{Ti}, \mathrm{Nb})(\mathrm{C}, \mathrm{N})$ and $(\mathrm{Ti}, \mathrm{Nb}) \mathrm{N}$ phase is preserved in the cores of many coarse particles (region 2 in Fig. 1). In all primary particles including their cores, Mo content was under detectable limits of EDS analysis. The results in Table 2 indicate that the increase of the $\mathrm{N}$ content in the composite leads to a reduction of the solubility of $\mathrm{Nb}$ in the MAX phase particles from 3.3 at.\% in the composite C5.0 to 0.4 at.\% in the N5.0. This decrease of $\mathrm{Nb}$ content in the MAX phase particles 
is clearly illustrated also in Fig. 3. The addition of a nearly equivalent amount of $\mathrm{C}$ and $\mathrm{N}$ in the composite $\mathrm{C} 2.5 \mathrm{~N} 2.5$ results in the nearly equivalent solubility of both elements in the $(\mathrm{Ti}, \mathrm{Nb})(\mathrm{C}, \mathrm{N})$, only partial substitution of $\mathrm{C}$ by $\mathrm{N}$ in $(\mathrm{Ti}, \mathrm{Nb})_{2} \mathrm{Al}(\mathrm{C}, \mathrm{N})$ and increased content of $\mathrm{N}$ in the lamellar $\alpha_{2}+\gamma$ matrix (Table 2). In all three studied composites, $\mathrm{Nb}$ and Mo segregate into the $\beta / \mathrm{B} 2$ phase formed along the grain boundaries (region 4 in Fig. 1 and Table 2), reaching up to 6 at.\% of $\mathrm{Nb}$ and 4 at.\% of Mo in this region.

Figure 4 shows the results of quantitative metallographic analysis of the in-situ composites. As seen in Fig. 4a, the increase of the content of $\mathrm{N}$ leads to a decrease in the volume fraction of the MAX phase particles and $\beta / \mathrm{B} 2$ regions and to an increase of the lamellar $\alpha_{2}+\gamma$ matrix. Figure 4b illustrates the effect of $\mathrm{Nb}, \mathrm{C}$ and $\mathrm{N}$ on grain size and size of the MAX

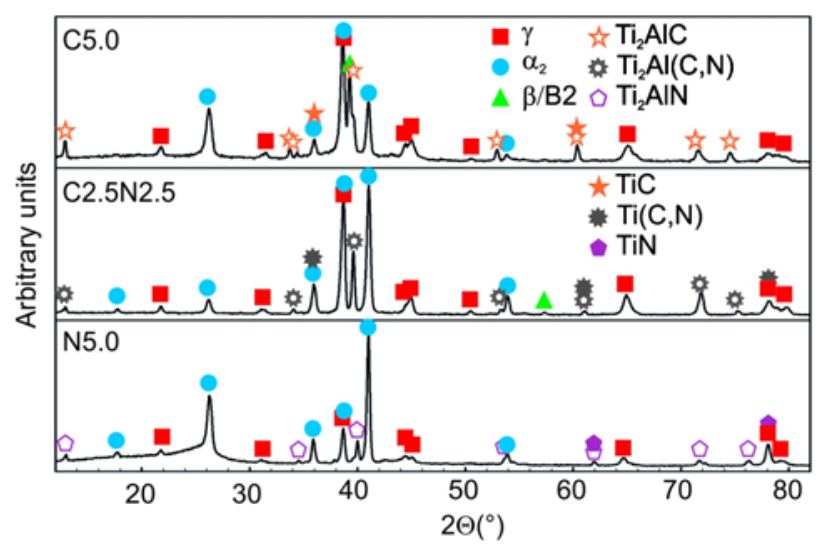

Fig. 2. XRD patterns of the C5.0, C2.5N2.5 and N5.0 insitu composites.
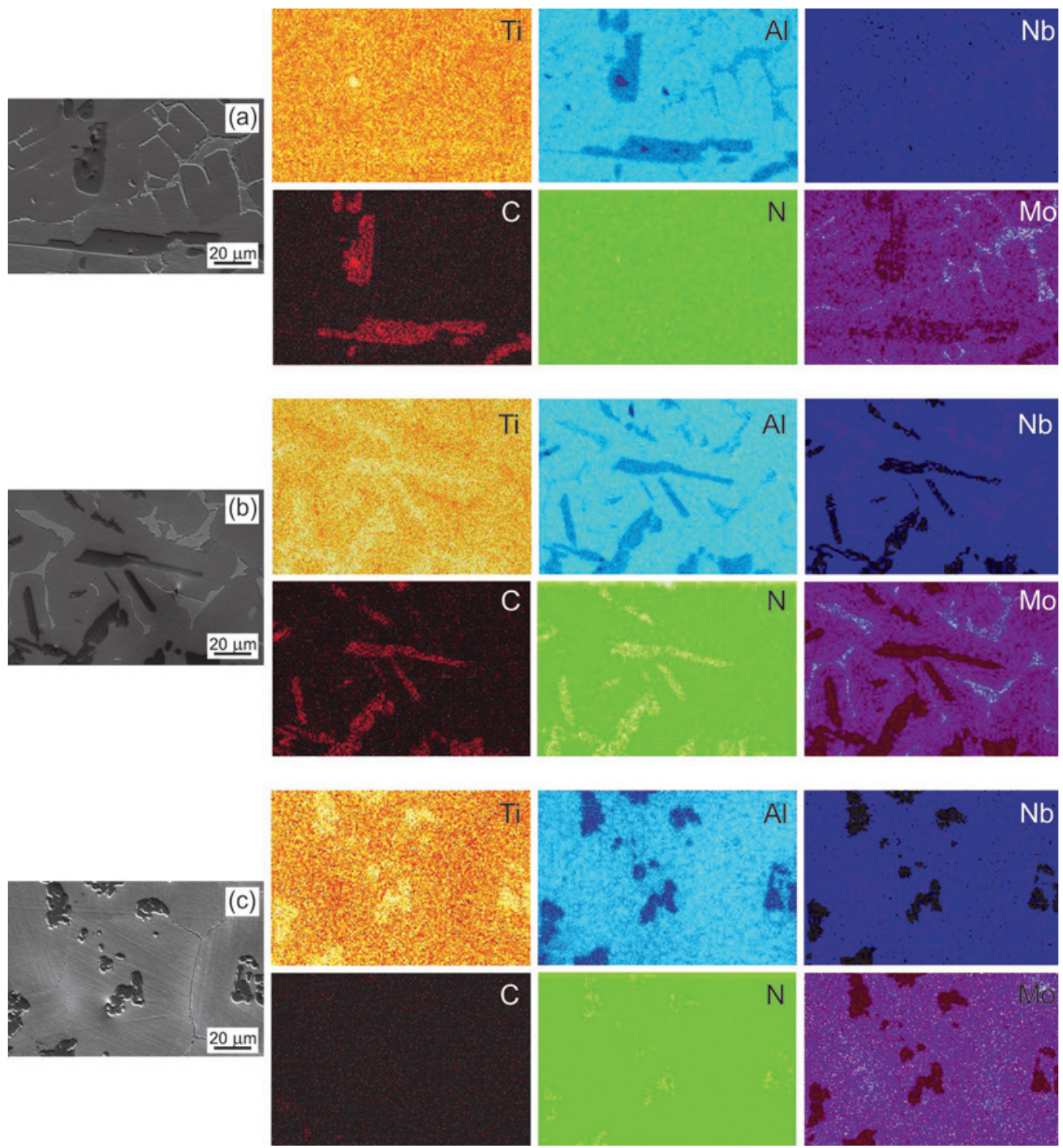

Fig. 3. EDS map analysis of in-situ composites: (a) C5.0; (b) C2.5N2.5; (c) N5.0. 
Table 2. Chemical composition of coexisting phases in C5.0, C2.5N2.5 and N5.0 in-situ composites (at.\%)

\begin{tabular}{|c|c|c|c|c|c|c|c|c|}
\hline \multirow{2}{*}{ Composite } & \multirow{2}{*}{ Region } & \multirow{2}{*}{$\begin{array}{c}\text { Phase } \\
\text { composition }\end{array}$} & \multicolumn{6}{|c|}{ Element } \\
\hline & & & $\mathrm{Ti}$ & $\mathrm{Al}$ & $\mathrm{Nb}$ & Mo & $\mathrm{N}$ & $\mathrm{C}$ \\
\hline \multirow[t]{4}{*}{ C5.0 } & 1 & $(\mathrm{Ti}, \mathrm{Nb})_{2} \mathrm{AlC}$ & $48.0 \pm 1.7$ & $23.5 \pm 2.4$ & $3.3 \pm 0.2$ & - & - & $25.2 \pm 1.2$ \\
\hline & 2 & $(\mathrm{Ti}, \mathrm{Nb}) \mathrm{C}$ & $52.6 \pm 2.1$ & $0.8 \pm 0.5$ & $2.2 \pm 0.7$ & - & - & $44.4 \pm 1.4$ \\
\hline & 3 & $\alpha_{2}+\gamma$ & $53.1 \pm 0.1$ & $41.4 \pm 0.2$ & $4.0 \pm 0.1$ & $1.0 \pm 0.1$ & - & $0.5 \pm 0.2$ \\
\hline & 4 & $\beta / \mathrm{B} 2$ & $55.0 \pm 0.4$ & $35.7 \pm 0.1$ & $5.6 \pm 0.2$ & $3.7 \pm 0.1$ & - & - \\
\hline \multirow[t]{4}{*}{$\mathrm{C} 2.5 \mathrm{~N} 2.5$} & 1 & $(\mathrm{Ti}, \mathrm{Nb})_{2} \mathrm{Al}(\mathrm{C}, \mathrm{N})$ & $49.6 \pm 0.5$ & $24.2 \pm 0.2$ & $1.3 \pm 0.1$ & - & $8.5 \pm 0.7$ & $16.4 \pm 0.8$ \\
\hline & 2 & $(\mathrm{Ti}, \mathrm{Nb})(\mathrm{C}, \mathrm{N})$ & $54.3 \pm 1.2$ & $1.5 \pm 0.5$ & $0.7 \pm 0.3$ & - & $21.8 \pm 2.3$ & $21.7 \pm 0.8$ \\
\hline & 3 & $\alpha_{2}+\gamma$ & $53.7 \pm 0.3$ & $39.8 \pm 0.3$ & $4.3 \pm 0.1$ & $1.0 \pm 0.1$ & $0.9 \pm 0.4$ & $0.3 \pm 0.2$ \\
\hline & 4 & $\beta / \mathrm{B} 2$ & $54.3 \pm 0.5$ & $35.6 \pm 0.3$ & $6.1 \pm 0.1$ & $4.0 \pm 0.5$ & - & - \\
\hline \multirow[t]{4}{*}{ N5.0 } & 1 & $(\mathrm{Ti}, \mathrm{Nb})_{2} \mathrm{AlN}$ & $53.2 \pm 2.8$ & $24.6 \pm 1.0$ & $0.4 \pm 0.1$ & - & $21.8 \pm 2.2$ & - \\
\hline & 2 & $(\mathrm{Ti}, \mathrm{Nb}) \mathrm{N}$ & $52.4 \pm 2.3$ & $0.3 \pm 0.1$ & $0.3 \pm 0.1$ & - & $47.0 \pm 2.4$ & - \\
\hline & 3 & $\alpha_{2}+\gamma$ & $53.3 \pm 1.7$ & $39.7 \pm 1.8$ & $4.6 \pm 0.2$ & $1.1 \pm 0.1$ & $1.3 \pm 0.5$ & - \\
\hline & 4 & $\beta / \mathrm{B} 2$ & $57.4 \pm 2.1$ & $34.7 \pm 1.9$ & $5.6 \pm 1.2$ & $2.3 \pm 1.1$ & - & - \\
\hline
\end{tabular}

phase particles. The increase of the content of $\mathrm{N}$ in the C2.5N2.5 composite leads to a decrease of grain size $D_{0}$ in comparison with that of the C5.0. The increase of $D_{0}$ in the N5.0 can be attributed to a peritectic reaction/transformation resulting in the growth of coarse $\alpha$ grains [26]. The major axis length $L_{\text {maj }}$ of the particles decreases and minor axis length $L_{\text {min }}$ varies with the increasing content of $\mathrm{N}$. The observed changes in the morphology, volume fraction and size of the primary particles with the increasing content of $\mathrm{N}$ at the expense of $\mathrm{C}$ content in the studied in-situ composites is assumed to be connected with the limited substitution of $\mathrm{C}$ by $\mathrm{N}$ in the MAX phases. This limited substitution of $\mathrm{C}$ by $\mathrm{N}$ is affected by alloying of the in-situ composites with $\mathrm{Nb}$, limited solubility of $\mathrm{Nb}$ in $(\mathrm{Ti}, \mathrm{Nb})_{2} \mathrm{AlN}$, as well as with the higher solubility of $\mathrm{N}$ in the matrix due to a smaller atomic radius of nitrogen than that of carbon $[7,8]$.

\subsection{Formation of primary $M A X$ phase particles}

According to thermodynamic calculations of $\mathrm{Ti}-$ -Al-C and Ti-Al-N systems [27, 28] and assuming measured substitution of alloying elements, the melt temperature of $1690{ }^{\circ} \mathrm{C}$ corresponds to L(liquid) + $(\mathrm{Ti}, \mathrm{Nb}) \mathrm{C}_{1-x} \mathrm{~N}_{x}$ phase region of the studied in-situ composites. During the cooling, a new phase equilibrium is achieved according to transformation pathway $\mathrm{L}+(\mathrm{Ti}, \mathrm{Nb}) \mathrm{C}_{1-x} \mathrm{~N}_{x} \rightarrow \mathrm{L}+(\mathrm{Ti}, \mathrm{Nb})_{2} \mathrm{Al}(\mathrm{C}, \mathrm{N})$. This reaction/transformation starts by the growth of solid $(\mathrm{Ti}, \mathrm{Nb})_{2} \mathrm{Al}(\mathrm{C}, \mathrm{N})$ layer at the $\mathrm{L} /(\mathrm{Ti}, \mathrm{Nb}) \mathrm{C}_{1-x} \mathrm{~N}_{x}$ interface and leads to a full transformation of small $(\mathrm{Ti}, \mathrm{Nb}) \mathrm{C}_{1-x} \mathrm{~N}_{x}$ particles to $(\mathrm{Ti}, \mathrm{Nb})_{2} \mathrm{Al}(\mathrm{C}, \mathrm{N})$. In the case of the coarse clustered $(\mathrm{Ti}, \mathrm{Nb}) \mathrm{C}_{1-x} \mathrm{~N}_{x}$ particles, continuous $(\mathrm{Ti}, \mathrm{Nb})_{2} \mathrm{Al}(\mathrm{C}, \mathrm{N})$ layer slows down the transformation and a small amount of untransformed
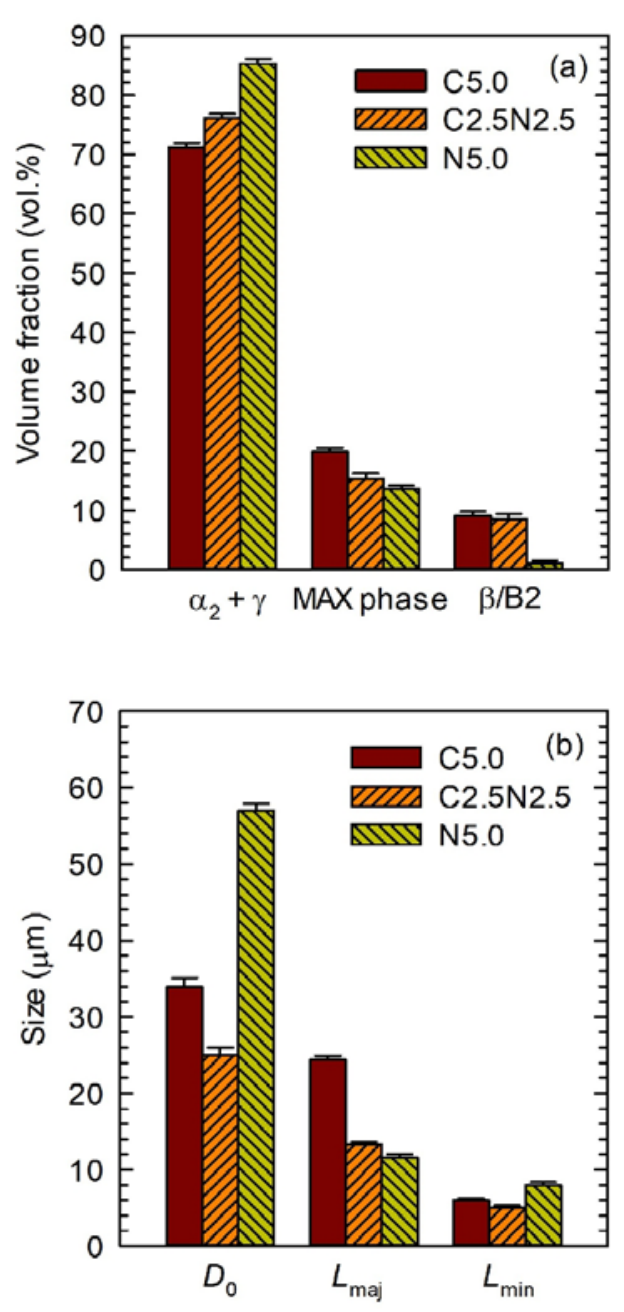

Fig. 4. (a) Volume fraction of lamellar $\alpha_{2}+\gamma$ matrix, MAX phase particles and $\beta / \mathrm{B} 2$ regions; (b) grain size $D_{0}$, length of major axis $L_{\text {maj }}$ and length of minor axis $L_{\text {min }}$ of MAX phase particles. 

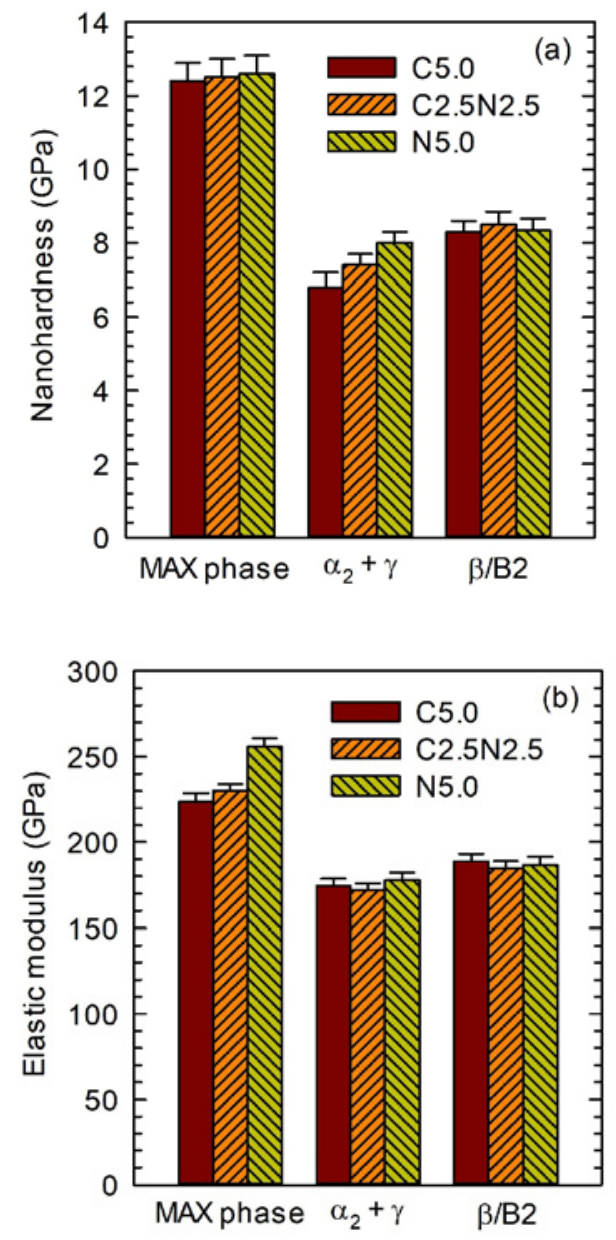

Fig. 5. (a) Nanohardness of MAX phase, lamellar $\alpha_{2}+$ $\gamma$ matrix and $\beta / \mathrm{B} 2$ regions; (b) elastic modulus of MAX phase, lamellar $\alpha_{2}+\gamma$ matrix and $\beta / \mathrm{B} 2$ regions.

$(\mathrm{Ti}, \mathrm{Nb}) \mathrm{C}_{1-x} \mathrm{~N}_{x}$ phase is preserved in the core of many coarse $(\mathrm{Ti}, \mathrm{Nb})_{2} \mathrm{Al}(\mathrm{C}, \mathrm{N})$ particles. The solidification continues with the formation of $\beta$-phase nucleating preferentially on the particles following the solidification sequences: $\mathrm{L}+(\mathrm{Ti}, \mathrm{Nb})_{2} \mathrm{Al}(\mathrm{C}, \mathrm{N}) \rightarrow \mathrm{L}+\beta+$ $(\mathrm{Ti}, \mathrm{Nb})_{2} \mathrm{Al}(\mathrm{C}, \mathrm{N}) \rightarrow \beta+\alpha+(\mathrm{Ti}, \mathrm{Nb})_{2} \mathrm{Al}(\mathrm{C}, \mathrm{N})$. The microstructure formation is finalized by the solid-state phase transformation sequences defined as: $\beta+\alpha+$ $(\mathrm{Ti}, \mathrm{Nb})_{2} \mathrm{Al}(\mathrm{C}, \mathrm{N}) \rightarrow \beta+\alpha+\gamma+(\mathrm{Ti}, \mathrm{Nb})_{2} \mathrm{Al}(\mathrm{C}, \mathrm{N})$ $\rightarrow \beta / \mathrm{B} 2+\alpha_{2}+\gamma+(\mathrm{Ti}, \mathrm{Nb})_{2} \mathrm{Al}(\mathrm{C}, \mathrm{N})$, where $\alpha$ is Ti-based solid solution with hexagonal structure.

\subsection{Nanohardness and elastic modulus}

Figures $5 \mathrm{a}, \mathrm{b}$ show that the increase of $\mathrm{N}$ and variation of $\mathrm{Nb}$ and $\mathrm{C}$ content increase the elastic modulus of the MAX phase particles but has a negligible effect on their nanohardness. The increase of the content of $\mathrm{N}$ increases nanohardness but does not affect the elastic modulus of the lamellar $\alpha_{2}+\gamma$ matrix. As shown by several authors $[2,8]$, the solubility limit of $\mathrm{C}$ and $\mathrm{N}$ in the $\alpha_{2}$-phase is 1.2 and 2.3 at.\%, respectively. The maximum solubility of $\mathrm{N}$ and $\mathrm{C}$ in the $\gamma$-phase of $\mathrm{Nb}$ doped alloy has been reported to be below 0.1 at.\% $[4,9]$. Content of nitrogen and carbon in the lamellar $\alpha_{2}+\gamma$ matrix of C2.5N2.5 and N5.0 (Table 2) indicate, that variations in the matrix nanohardness can be attributed to the hardening effects of $\mathrm{C}$ and $\mathrm{N}$ by the mechanisms of solid solution strengthening and possibly also by precipitation of secondary carbide/nitride particles at the $\alpha_{2} / \gamma$ interfaces during transformation processes after melting $[1,29,30]$. The variation of $\mathrm{C}$ and $\mathrm{N}$ content has no significant effect on the nanohardness and elastic modulus of the $\beta / \mathrm{B} 2$ regions which are higher than those of the lamellar $\alpha_{2}+\gamma$ matrix but lower than those of the MAX phase particles.

\section{Conclusions}

The increasing content of $\mathrm{N}$ in the studied in-situ composites decreases the solubility of $\mathrm{Nb}$ in the primary $(\mathrm{Ti}, \mathrm{Nb})_{2} \mathrm{Al}(\mathrm{C}, \mathrm{N})$ particles. The addition of a nearly equivalent amount of $\mathrm{C}$ and $\mathrm{N}$ leads to a partial substitution of $\mathrm{C}$ by $\mathrm{N}$ in the MAX phase particles and an increase of the content of $\mathrm{N}$ in the lamellar $\alpha_{2}+\gamma$ matrix. The volume fraction and size of the primary particles decrease, and their shape factor increases with increasing content of $\mathrm{N}$. The increasing content of $\mathrm{N}$ increases elastic modulus of the primary MAX phase particles but has no effect on their nanohardness. These results indicate, that substitution of $\mathrm{C}$ by $\mathrm{N}$ in the in-situ Ti-Al-Nb-Mo-C-N composites leads to the significant changes in the chemistry, size and morphology of the primary MAX phase particles and contributes to the hardening of the matrix.

\section{Acknowledgement}

This work was financially supported by the Slovak Research and Development Agency under the contract APVV-15-0660.

\section{References}

[1] Schwaighofer, E., Rashkova, B., Clemens, H., Stark, A., Mayer, S.: Intermetallics, 46, 2014, p. 173. doi:10.1016/i.intermet.2013.11.011

[2] Klein, T., Schachermayer, M., Mendez-Martin, F., Schöberl, T., Rashkova, B., Clemens, H., Mayer, S.: Acta Mater., 94, 2015, p. 205. doi:10.1016/j.actamat.2015.04.055

[3] Scheu, C., Stergar, E., Schober, M., Cha, L., Clemens, H., Bartels, A., Schimansky, F. P., Cerezo, A.: Acta Mater., 57, 2009, p. 1504. doi:10.1016/j.actamat.2008.11.037 
[4] Zhang, T., Wu, Z., Hu, R., Zhang, F., Kou, H., Li, J.: Mater. Design, 103, 2016, p. 100. doi:10.1016/j.matdes.2016.04.071

[5] Nam, C. Y., Oh, M. H., Kumar, K. S., Wee, D. M.: Scripta Mater., 46, 2002, p. 441. doi:10.1016/S1359-6462(02)00011-8

[6] Menand, A., Huguet, A., Nérac-Partaix, A.: Acta Mater., 44, 1996, p. 4729. doi:10.1016/S1359-6454(96)00111-5

[7] Perdrix, F., Trichet, M. F., Bonnentien, J. L., Cornet, M., Bigot, J.: Intermetallics, 9, 2001, p. 807. doi:10.1016/S0966-9795(01)00066-8

[8] Perdrix, F., Trichet, M. F., Bonnentien, J. L., Cornet, M., Bigot, J.: Intermetallics, 9, 2001, p. 147. doi:10.1016/S0966-9795(00)00120-5

[9] Wu, Z., Hu, R., Zhang, T., Zhang, F., Kou, H., Li, J.: Mater. Charact., 124, 2017, p. 1. doi:10.1016/i.matchar.2016.12.008

[10] Barsoum, M. W., Radovic, M.: Annu. Rev. Mater. Res., 41, 2011, p. 195. doi:10.1146/annurev-matsci-062910-100448

[11] Chen, R., Fang, H., Chen, X., Su, Y., Ding, H., Guo, J., Fu, H.: Intermetallics, 81, 2017, p. 9. doi:10.1016/j.intermet.2017.02.025

[12] Fang, H., Chen, R., Yang, Y., Su, Y., Ding, H., Guo, J., Fu, H.: Mater. Design, 156, 2018, p. 300. doi:10.1016/j.matdes.2018.06.048

[13] Lapin, J., Klimová, A., Gabalcová, Z., Pelachová, T., Bajana, O., Stamborská, M.: Mater. Design, 133, 2017, p. 404. doi:10.1016/j.matdes.2017.08.012

[14] Lapin, J., Klimová, A., Stamborská, M., Kamyshnykova, K., Pelachová, T.: Mater. Sci. Forum, 941, 2018, p. 1907. doi:10.4028/www.scientific.net/MSF.941.1907

[15] Klimová, A., Lapin, J., Pelachová, T.: In: IOP Conf. Ser. Mater. Sci. Eng., 179, 2017, 012038. doi:10.1088/1757-899X/179/1/012038

[16] Song, X. J., Cui, H. Z., Hou, N., Wei, N., Han, Y., Tian, J., Song, Q.: Ceram. Int., 42, 2016, p. 13586. doi:10.1016/j.ceramint.2016.05.152
[17] Lapin, J., Stamborská, M., Pelachová, T., Bajana, O.: Mater. Sci. Eng. A, 205, 2018, p. 113. doi:10.1016/j.msea.2018.02.077

[18] Stamborská, M., Lapin, J., Bajana, O.: Kovove Mater., 56, 2018, p. 349. doi:10.4149/km_2018_6_349

[19] Lapin, J., Kamyshnykova, K.: Intermetallics, 98, 2018, p. 34. doi:10.1016/i.intermet.2018.04.012

[20] Song, X., Cui, H., Han, Y., Hou, N., Wei, N., Ding, L., Song, Q.: Mater. Sci. Eng. A., 684, 2017, p. 406. doi:10.1016/j.msea.2016.12.069

[21] Yu, W., Mauchamp, V., Cabioc'h, T., Magne, D., Gence, L., Piraux, L., Gauthier-Brunet, V., Dubois, S.: Acta Mater., 80, 2014, p. 421. doi:10.1016/i.actamat.2014.07.064

[22] Aryal, S., Sakidja, R., Ouya, L., Ching, W. Y.: J. Eur. Ceram. Soc., 35, 2015, p. 3219. doi:10.1016/j.jeurceramsoc.2015.03.023

[23] Salama, I., Barsoum, M. W.: J. Alloys Compd., 347, 2002, p. 271. doi:10.1016/S0925-8388(02)00756-9

[24] Hug, G., Jaouen, M., Barsoum, M. W.: Phys. Rev. B - Condens. Matter Mater. Phys., 71, 2005, p. 1. doi:10.1103/PhysRevB.71.024105

[25] Song, X., Cui, H., Han, Y., Ding, L., Song, Q.: ACS Appl. Mater. Interfaces, 10, 2018, p. 16783. doi:10.1021/acsami.8b02023

[26] Kamyshnykova, K., Lapin, J.: Kovove Mater., 56, 2018, p. 277. doi:10.4149/km_2018_5_277

[27] Witusiewicz, V. T., Hallstedt, B., Bondar, A. A., Hecht, U., Sleptsov, S. V., Velikanova, T. Y.: J. Alloys Compd., 623, 2015, p. 480. doi:10.1016/j.jallcom.2014.10.119

[28] Zhang, Y., Franke, P., Seifert, H. J.: Calphad, 59, 2017, p. 142. doi:10.1016/j.calphad.2017.09.006

[29] Wang, D., Sun, D., Han, X., Wang, Q.: Mater. Sci. Eng. A, 742, 2019, p. 231. doi:10.1016/j.msea.2018.11.018

[30] Lapin, J., Stamborská, M., Kamyshnykova, K., Pelachová, T., Klimová, A., Bajana, O.: Intermetallics, 105, 2019, p. 113. doi:10.1016/j.intermet.2018.11.007 